\title{
The Effect of Cooperative Model "Jigsaw Type" in Improving Students' Achievement at Christian Education Subject Case: Grade XII IPA 1-2 SMA Negeri 1 Tebing Syahbandar
} Bangun Munte

\author{
bangunmunte1@gmail.com
}

\begin{abstract}
This research intends to find out the extent of effect of Cooperative Jigsaw Type improve students' achievement of grade XII IPA 1-2 SMA Negeri 1 Tebing Syahbandar. The population is all the students of Christian at the school. They are 40 students at the first semester. Sample is grade XII IPA-1 as the control class and IPA-2 as the experiment class. Each of the class consists of 20 students. Technique of data analysing uses statistic parametric, it is normality test to measure chi quadrat test. Homogeneity test uses F-test and hypothesis uses t-test. The result of pre-test of mean experimenlt class is 37,25 and standard deviation is 11,97. Then pre-test of mean control class is 31,5 and standard deviation is 13,29. Then the result of post-test of mean experimental class is 57,25 and standard deviation is 18,10. The post-test of mean control class is 44 and standard deviation is 17,21. Hypothesis shows that $t_{\text {-test }}=2,37$ and $t_{\text {-table }}=1,70, t_{\text {-test }}>t_{\text {-table }}(2,37>$ 1,70) which mean that hypothesis is accepted. From this data analysis result, can be concluded that Cooperative Jigsaw Type has significant effect in improving students' achievement at Christian education subject at grade XII IPA SMA Negeri 1 Tebing Syahbandar of academic year $2018 / 2019$.
\end{abstract}

Keywords-the effect of cooperative "jigsaw type", improving, students' achievement.

\section{INTRODUCTION}

The world of education today is focused on improving quality human resources because education is an important vehicle for building students. Education is a systematic and continuous process of activities to shape the personality of students so that they have provisions aimed at enhancing one's ability in all fields including knowledge, skills, and attitudes that are professional in their respective fields, broad-minded and able to work together to develop quality of life the dignity of the Indonesian people. The role of the teacher is very important to improve student learning skills both individually and in groups. The teacher seeks to create events that can improve and facilitate learners to learn, teachers must really understand the concepts or learning materials in supporting the achievement of learning goals. According to Abdul Hamid (2009: 2) who quoted Gagne's opinion (1975) "there are three functions that can be played by the teacher in teaching, namely as a learning designer, learning manager and as a learning evaluator". In teaching the teacher not only explain and deliver material but also must give encouragement or motivation to students, so students can improve their learning outcomes. Talking about education problems cannot be separated from learning because learning is at the core of the education process. Improving the quality of education shows the efforts to improve the quality of learning processes and outcomes. Students who study in school are a result of teacher learning programs, teachers have an interest in encouraging active students to learn. Thus as educators of the nation's young generation, teachers are obliged to find and find learning problems faced by students. Teachers must understand various learning models and be able to choose the right model and can use models that vary according to the objectives to be achieved. Dimyati (2013: 50) said that "Students as (primus motor) in learning activities, for whatever reason cannot simply ignore the principles of learning. Instead, students will succeed in learning, if they are aware of the implications of the principles of learning towards themselves". First, attention and motivation. Students are required to give attention to all stimuli that lead to the achievement of learning goals. The principle of motivation for students is to realize and develop continuously. Second, activeness. Students are required to always actively process and process their learning effectively. The activeness of students demands direct involvement of students in the learning process such as 
finding sources of information, analyzing the results of trials, making papers, and others. Activity for students further requires students' direct involvement in the learning process. Third, direct involvement / experience. With direct involvement logically will cause students to gain experience. The form of direct student involvement behavior does not absolutely guarantee the realization of the principle of activeness in students. Fourth, repetition. Forms of learning behavior which are the implications of the principle of repetition, including memorizing and working on questions. Fifth, challenge. Students always face challenges to obtain, process and process every message that is in learning activities. Sixth, feedback or reinforcement. Through the results of observations made by Jigsaw learning model researchers gave a positive influence in Teaching and Learning activities (KBM), namely: students can follow Teaching and Learning Activities (TLA) well, can master the subject matter, and it useful for the studnets. (Martinis Yamin, 2014: 92) The Jigsaw learning model is a cooperative learning model where students learn in small groups consisting of 4-6 people heterogeneously and work together with each other in positive interdependence and are responsible for completing the part of the subject matter that must be learned and deliver the material to other group members ght to students, students have good achievements and this is beneficial for students. Students not only study the material provided, but they must also be ready to provide and teach the material to other group members. The teacher no longer acts as an information provider and students are no longer the recipients of information even though it is very necessary. Learning outcomes are abilities acquired by children through learning activities. Learning outcomes are usually directed at one area of the taxonomy. Benyamin S. Bloom sorts the taxonomy of learning in three regions, namely (1) Cognitive, (2) Affective, (3) Psychomotor. Student learning outcomes are influenced by internal factors and external factors. Internal factors include the characteristics of students, attitudes toward learning, motivation to learn, concentration of learning, processing learning materials, exploring learning outcomes, self-confidence and learning habits while external factors are teachers, social environment, school curriculum, facilities and infrastructure. Therefore a PAK teacher must be able to overcome these two factors in order to realize satisfying student learning outcomes, where both factors are interrelated to achieve educational goals. Especially on external factors come from educator or teacher, one of which is the learning method. One of the external factors that influence the learning outcomes of Christian Education
Subject is because the teacher's teaching method always uses the old method, namely lecture. Students become bored, sleepy, passive and just take notes. So that the attitude of students when learning Crhistian education subject they are lazy to follow Teaching and Learning Activities (TLA), do not master the subject matter well, have insufficient insight so that students do not benefit from learning. The absence of learning dynamics that are used causes students to be less interested in participating in PAK learning which results in their learning outcomes tend to be low. Progressive teachers dare to try new methods, which can help improve teaching and learning outcomes, and increase students' motivation to learn. In order for students to learn well, the teaching method must be tried in an appropriate, efficient and effective manner. In this case, it takes educators who have creativity in using learning models so that students can be more motivated by Christian education subject lessons and interact with each other so that optimal learning outcomes can be obtained and meet educational goals. Students must be required to be active and teachers as motivators and facilitators in it so that the classroom atmosphere is more lively. At all levels of education, Christian education subjects are required to be given including high school. For example, Christian education learning at SMA 1 Tebing Syahbandar, es pecially class XI IPA 1-2 based on temporary observations, often experiences obstacles and difficulties in achieving expected learning outcomes. So far, the Christian education subject learning process in most classes still uses the old paradigm. Teachers teach with conventional methods namely by lecturing and discussion methods and expecting students to sit down, be quiet, listen, note and memorize (3 DCH). So that Teaching and Learning (TLA) Activities tend to be monotonous, less attractive to students, less varied and often placing the teaching and learning process that is only teacher-centered and leads to the formation of attitudes of students who are apathetic to accept what they are. This ultimately results in students becoming bored and not serious in facing lessons. Such teaching conditions result in the achievement of the minimum criteria of Christian education subject value of high school students unsatisfactory if left continuously, of course it will harm students, both informative losses and disadvantages to inappropriate learning outcomes because many students do not understand the lesson. Such conditions will not improve students in understanding Christian education subjects, so the Christian subject learning objectives will never be achieved. 


\section{REVIEW OF RELATED LITERATURE}

Cooperative learning model is one learning model that has certain rules. The basic principle of cooperative learning is that students form small groups and teach each other to achieve common goals. In cooperative learning students are good at teaching students who are less intelligent without feeling disadvantaged. Less intelligent students can learn in a pleasant atmosphere because many friends help and motivate them. Students who were previously used to being passive after using cooperative learning will be able to actively participate in order to be accepted by group members. Slavin in Isjoni (2009: 15) cooperative learning is a learning model where students learn and work in small groups collaboratively whose members are 5 people with a heterogeneous group structure. Whereas according to Sunal and Hans in Isjoni (2009: 15) suggests that cooperative learning is a method of approach or a series of strategies specifically designed to encourage students to work together during the learning process. Furthermore, Stahl in Isjoni (2009: 15) states that cooperative learning can improve student learning better and increase mutual help in social behavior. Cooperative learning is a learning model that focuses on using small groups of students to work together in maximizing learning conditions to achieve learning goals (Sugiyanto, 2010: 37). Anita Lie (2007: 29) revealed that cooperative learning learning models are not the same as just learning in groups. Agus Suprijono (2009: 54) suggests that cooperative learning is a broader concept covering all types of group work including forms that are more led by the teacher or directed by the teacher. In general, cooperative learning is considered more directed by the teacher, where the teacher determines tasks and questions and provides materials and information designed to help students solve the intended problem. The teacher usually sets the form of a particular test at the end of the task. From several definitions put forward by the experts above, it can be concluded that cooperative learning is a learning model that places students in small groups whose members are heterogeneous, consisting of students with high, moderate, and low achievement, women and men men with different ethnic backgrounds to help each other and work together to learn subject matter so that all members learn best.

There are several types of variants in cooperative learning, as follows:
1. STAD Model
2. Jigsaw model
3. Pair Making Model
4. Group Investigation
5. Game Tournaments Teams Model
6. Structural Model

Things that must be considered by educators in the jigsaw method, there are 5 basic components of jigsaw learning. These components distinguish between learning and ordinary group activities. Many group activities that you have used in the past can be adapted to jigsaw learning by adjusting activities by including the components below:

1. In Jigsaw learning, all group members need to work together to complete the task.

2. The Jigsaw learning group should be heterogeneous.

3. Jigsaw learning activities need to be designed so that each student contributes to the group can be assessed on the basis of performance.

4. The Jigsaw learning team needs to know the academic and social goals of a lesson.

5. The media used for group presentations, e.g. laptops, in focus.

Steps to Implement Type Jigsaw Cooperative Learning This learning model is a model that is quite time-consuming and technically students must really understand the learning path. Because if you forget or don't understand it will make this learning model become noisy in its implementation. The steps for applying the jigsaw learning model in the book Aris Shoimin (2016: 91) are:

- The first step

The teacher plans learning that will connect several concepts in one time span simultaneously. The teacher can describe the topic content in general, as well as motivate students and explain the purpose of studying the topic to be discussed.

-Second step

Prepare lesson material for each concept so the teacher has the type of subject matter.

- Third step

The teacher prepares a quiz or test according to the subject matter to be studied by students.

- Fourth step

Divide the class into four groups. The teacher presents an introduction to group discussion by explaining very briefly 1) the topics to be studied by each group, 2) the expected goals and indicators of learning, 3) the procedure of activities, 4) learning resources that can be used by students. The discussion began, students actively studied the material, the teacher became the monitor and facilitator. Each group prepares to study one material and from the material each group will receive a predetermined sub-topic. During the discussion each group can ask each other to get 
understanding. This origin group or study group in English is called a home group. At the end of each group the origin understands one topic so that they can deliver the material to other groups. After meeting the target time and based on monitoring the teacher the student has sufficient understanding of the material, and the discussion is temporarily closed.

\section{- Fifth Step}

Each group explores the material that it holds, explores the facts, concepts and procedures for applying the concept so that the knowledge they learn can be conveyed back to their friends. In this phase there is no interaction in the original group. This reflection activity is a process of increasing mastery of material to face the expert team discussion round.

- Sixth step

Students form expert groups and return to discussion. Each group discusses one material that becomes his area of expertise. Here there is a critical period that the teacher needs to monitor in each group. Ensure that concepts that students develop in accordance with what they should.

- Seventh step

After studying the material through expert group discussions, students returned to the study group. The results of the discussion in the expert group are discussed again in the original group. In the final stage of the learning activity, each group originates to convey the results of the discussion to the expert group. In this way all students repeat all the material that must be mastered. Each group member has a record of the results of the discussion at stage one, stage two of the expert team discussion and returns to the original group.

- Eighth step

The teacher measures student learning outcomes with a test or quiz. The teacher can assess the level of mastery of learning by comparing the results that students achieve with the targets set by the lesson planning.

\section{The Advantages of the Jigsaw Learning Model}

Jigsaw is a learning model that teaches students through peers and creates a spirit of cooperation and fosters a responsibility. In addition to creating cooperation in learning to know and know about something, students are also respected or given trust by the teacher and friends of his group to master a topic and people who will then return the group to explain to their friends. In the jigsaw learning model, students have many opportunities to express opinions and process information obtained and can improve communication skills. Students must have responsibility and positive cooperation and interdependence to get information and solve problems given. The jigsaw process is used to improve individual learning, creating sensitivity to what is happening and fostering individual, social and academic development. The Jigsaw model of cooperative learning is a cooperative learning model that focuses on student group work in the form of small groups. As revealed by Lie (1999: 73), that "Jigsaw cooperative learning is a cooperative learning model by means of students learning in small groups consisting of 4-6 people heterogeneously and students collaborating on positive interdependence and responsible independently". Anita Lie (1994) states that Jigsaw is a type or flexible cooperative learning model. Much research has been done relating to cooperative learning on the basis of Jigsaw. The research has consistently shown that students involved in the Jigsaw model of cooperative learning get better performance, have better and more positive attitudes towards learning, besides respecting each other's differences and opinions.Learning is doing and at the same time is a process that makes students must be active, active activities where students learn to build their own knowledge. Students learn by themselves looking for the meaning of something they learn. So in essence, the purpose of learning is to get knowledge, skills and planting mental attitudes or values. According to Bneyamin Bloom (Sudjana 2009: 22). Cognitive domain with regard to intellectual student learning outcomes consisting of 6 aspects, and researchers take 4 of the 6 aspects namely knowledge or memory, understanding, application, analysis. While according to Makmun Khairani (2017: 61) cognitive theory is a theory that is generally associated with the teaching and learning process. Cognition is a psychic or mental ability of humans in the form of observing, thinking, paying attention, guessing and researching. In other words, cognition refers to the concept of recognition.

\section{RESEARCH METHODOLOGY}

According to Soerjono (1986: 5), research is a scientific activity related to analysis and construction carried out methodologically, systematically, and consistently. Draw conclusions from the discussion, that the system and methods used to obtain information or material material are scientific knowledge called "scientific methodology". To describe the research methodology used in solving research problems, it is necessary to briefly explain the operational definition of the independent variable $(\mathrm{X})$ and the 
dependent variable (Y). In this study the sample will be divided into 2 groups, namely the control class and the experimental class. A control class is a class that is taught without using teaching aids. Whereas the intended experimental class in this case is a class taught using a jigsaw model. To avoid the results of ordinary research, the two groups are first neutralized (uniform) in learning by:

1. The teacher who teaches both classes is the same

2. The student handbook must be equated
3. The length of time the material is delivered must be the same

4. The time interval for giving material is not too long between the two groups

5. The number of sample questions and exercises made must be the same

6. The atmosphere of the classroom (environment) is as much as possible equated

So what distinguishes the two groups only in the experimental class is given teaching using a jigsaw model:

Table.3.1 Research Design

\begin{tabular}{|l|l|l|l|}
\hline Method & Pretest & Action & Postest \\
\hline Control & $\mathrm{T}_{11}$ & $\mathrm{X}_{1}$ & $\mathrm{~T}_{21}$ \\
\hline Experiment & $\mathrm{T}_{12}$ & $\mathrm{X}_{2}$ & $\mathrm{~T}_{22}$ \\
\hline
\end{tabular}

$\mathrm{X}_{1} \quad$ : experiment ( without using jigsaw model)

$\mathrm{X}_{2} \quad$ : experiment ( using jigsaw model)

$\mathrm{T}_{11} \quad$ : Score of pre-test at control class

$\mathrm{T}_{12} \quad$ : Score of pre-test at experiment class

$\mathrm{T}_{21} \quad$ : score of post-test at eks perimen class

\section{Techniques of Collecting Data}

1. Conducting a pre-test

Before carrying out teaching, pretest is held before the two classes. The aim is to find out the extent of students' knowledge on the subject.

2. Conducting treatment to the control group, namely teaching without using a jigsaw model and treating the experimental group using a jigsaw model.

3. Conducting a post test (final test)
After the material is taught, a post test is held, with the aim of knowing the extent to which the results of the teaching are carried out.

\section{Research Finding and Discussion}

From the research data, in the form of data which is the result of the pre-test and post-test of the experimental class and the control class obtained an average score, standard deviation, variance. To see clearly the research data we can see in the following table.

Table.4.1: Result of Pre Test and Post Test of Eksperimental Class

\begin{tabular}{|c|c|c|}
\hline Statistics & Pre Test & Post Test \\
\hline Sampel & 20 & 20 \\
\hline Everage & 37.25 & 57.25 \\
\hline Standart Deviation & 11.97 & 18.10 \\
\hline Varians & 143,36 & 327.57 \\
\hline
\end{tabular}


Result of Pre Test Dan Post Test Eksperimen Class

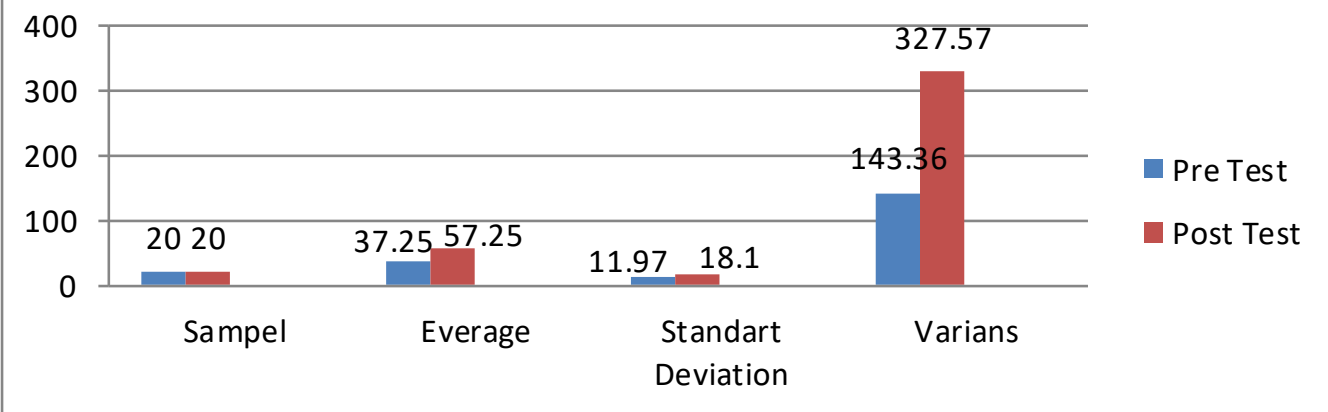

Table.4.2: Result of Pre Test dan Post Test Control Class

\begin{tabular}{|c|c|c|}
\hline Statistic & Pre Test & Post Test \\
\hline Sample & 20 & 20 \\
\hline Mean & 3.5 & 44 \\
\hline Standard Deviation & 13.29 & 17.29 \\
\hline Variance & 176.56 & 296.31 \\
\hline
\end{tabular}

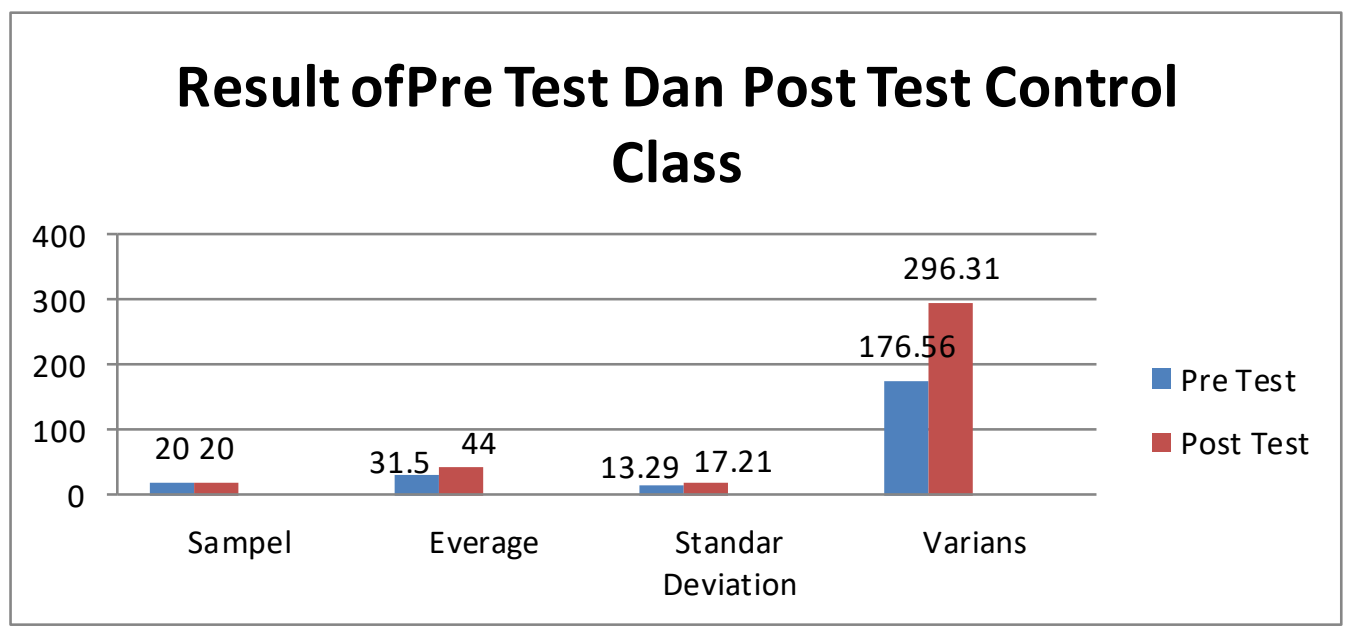

Based on tables 1 and 2, the average score of the pre test for the experimental class is 37.25 with the highest score of 60 and the lowest value is 20 , and the standard deviation is 11.97, the variance is 143.36 . Whereas for the post test the average score was 57.25 with the highest score 85 and the lowest 30 . The standard deviation was 18.10 , the variance was 327.57. While the average score of the pre test for the control class is 31.5 with the highest value of 65 and the lowest value is 10 , and the standard deviation is 13.29 variance of 176.56. Whereas for the post test obtained an average score of 44 , with the highest value 85 and the lowest 20 , and the standard deviation of 17.21 , the variance of 296.31 .

\section{Hypothesis}

The two groups of data are normally distributed and have the same variance (homogeneous), thus hypothesis testing is done through a two-mean difference test or test.From the results of calculations in appendix 9 , it is obtained that $t$ counts with $\mathrm{t}$ table for $\alpha=0.05$ and $\mathrm{dk}=38$ obtained by $\mathrm{t}$ table $=1.70$ so that it can be expressed $\mathrm{t}$ count $>\mathrm{t}$ table (2.370> 1.70). Thus $\mathrm{HO}$ is rejected and $\mathrm{Ha}$ is accepted. So the conclusion is "There is an increase in the learning 
outcomes of Christianity taught by using the Jigsaw model for students of class XII IPA in SMA 1 Tebing Syahbandar". It turns out that the learning outcomes of students taught using the Jigsaw learning model are higher than the learning outcomes of students who are taught without using the Jigsaw model.

\section{DISCUSSION}

From the results of the study, data obtained from the Christian religious learning of students on Human Rights learning from the research groups, namely, for Experimental Classes (taught using the Jigsaw model) with an average pre-test 37.25 and post-test 57.25, standard deviation pre-test 11.97 and post-test 18.10, while for the Control Class (taught without using the Jigsaw model) with an average pre-test 31.5 , and post-test 44 standard deviation pre-test 13.29, and post-test 17,21 From the above results, the group taught using the Jigsaw model is higher than the group taught without using the Jigsaw model, because learning with the Jigsaw model makes it easier for students to better understand the material being taught and can arouse students' enthusiasm so that learning outcomes are more high compared to the learning outcomes of students taught by not using the Jigsaw model. To strengthen the results of the study also tested the hypothesis statistically, before carrying out statistical tests before the normality test was conducted to find out whether the sample was normally distributed or not and homogeneity test to find out the similarity (homogeneity) of samples, namely the uniform variance of samples taken from same population.

\section{CONCLUSION}

1. The results of the Christian Religious Education Experiment class using the Jigsaw learning model were higher than the control class that did not use the Jigsaw model. This can be seen from the average learning outcomes of the Christian Experimental class of 57.25 while the control class average is 44 .

2. Based on the $\mathrm{t}$ test, where thitung > t table (2.37> 1.70), it means that the hypothesis is accepted, namely there is an increase between the results of Christian religious learning students taught using the Jigsaw model rather than not using the Jigsaw model on the subject of Human Rights in class XII IPA of SMA 1 Tebing Syahbandar in Academic Year 2018/2019.

\section{REFERENCES}

[1] Alkitab. Jakarta: Lembaga Alkitab Indonesia

[2] Budiyana, H.(2011), Dasar-dasar Pendidikan Agama Kristen. Yogyakarta : Berita Hidup Seminary
[3] Boehlke R,R.(1994). Sejarah Perkembangan Pemikiran dan Praktik PAK dari Plato sampai Ig.Loyola. Jakarta : BPK Gunung Mulia

[4] Dimyati. (2013). Belajar dan Pembelajaran. Jakarta : Rineka Cipta

[5] E.G, Homrighausen dan I. H, Enklaar.(2011). Pendidikan Agama Kristen. Medan : BPK Gunung Mulia.

[6] Hamalik, O. (2013). Kurikulum dan Pembelajaran. Bandung : Bumi Aksara

[7] Istirani \& Intan Pulungan. (2017). Ensiklopedia Pendidikan. Medan : Persada

[8] Istirani. (2011). 58 Model Pembelajaran Inovatif. Medan : Persada

[9] K, Hamid Abdul. (2009). Teori Belajar dan Pembelajaran. Medan : Unimed

[10] Lie, A. (2010). Cooperative Learning. Jakarta : PT Gramedia

[11] Mudjiono dan Dimyati.(2013). Belajar dan Pembelajaran. Jakarta :Rineka Cipta

[12] Sadirman. (2011). Interaksi dan Motivasi Belajar Mengajar. Jakarta : PT. Raja Grafindo.

[13] Sudjana. (1984). Metode Statistik. Bandung: Tarsito

[14] Sugiono.(2009). Metode Penelitian Pendidikan. Bandung : Alfabet

[15] Sugiono. (2010). Metode Penelitian Kualitatif dan $R$ \& D. Bandung: IKPI 